Hege Myklebust

Western Norway University of Applied Sciences

Sissel Høisceter

Western Norway University of Applied Sciences

DOI: http://dx.doi.org/10.5617/adno.4727

\title{
Written Argumentation for Different Audiences. A Study of Addressivity and the Uses of Arguments in Argumentative Student Texts
}

\begin{abstract}
In this article we investigate how students in upper secondary school argue in writing in two different communicative situations and how the intended audience may influence how the students construct their arguments.

A class of social science students was instructed to write a text arguing for how we may best prevent crime. The text was to be handed in as homework within the week. The same week, the students were instructed to write a text in an online discussion forum about a topic relevant to social science, arguing in favor of their opinion. We collected 34 texts from 17 students in one class, one from each student in each of the two communicative situations.

Our findings show that although the students in both tasks were asked to argue for an opinion, the argument fulfills different purposes in the different situations, and the different audiences played an important role in the way the argumentation was carried out. The students tend to argue with intellectual appeal, using data from reliable sources when arguing for the teacher. When they write for the general public online, they tend to argue with emotional appeal, using data from their own values instead of other sources.

Our findings may contribute to improving the construction of writing tasks for argumentative writing as well as to the ongoing debate about authentic writing situations among writing researchers across the world.
\end{abstract}

Keywords: writing, argumentation, addressivity, Toulmin 


\section{Skriftleg argumentasjon for ulike publikum. Ein studie av adressivitet og bruk av argument $\mathrm{i}$ argumenterande elevtekstar}

\section{Samandrag}

I denne artikkelen undersøker me korleis elevar i vidaregåande skule argumenterer skriftleg $i$ to ulike kommunikasjonssituasjonar, og korleis det intenderte publikummet kan påverka korleis elevane konstruerer argumenta sine.

Ein klasse samfunnsfagelevar vart bedne om å skriva ein tekst der dei argumenterer for korleis me best kan førebyggja kriminalitet. Teksten skulle leverast inn som lekse i løpet av veka. Same veka vart elevane bedne om å skriva ein tekst på eit diskusjonsforum på nettet, om eit emne som var relevant for samfunnsfag, der dei argumenterte for si eiga meining. Me samla inn 34 tekstar frå 17 elevar i ein klasse, ein frå kvar elev i kvar av dei to kommunikasjonssituasjonane.

Funna våre viser at sjølv om elevane $i$ begge oppgåvene vart bedne om å argumentera for eit synspunkt, fyller argumentasjonen ulike føremål i dei ulike situasjonane, og dei ulike publikumma spela ei viktig rolle i korleis argumentasjonen vart gjennomført. Elevane har ein tendens til å argumentera med intellektuell appell, ved hjelp av underbygging frå truverdige kjelder når dei argumenterer overfor lceraren. Når dei skriv for det generelle publikummet på nettet, har dei ein tendens til å argumentera med appell til kjensler, og underbygger med eigne verdiar $i$ staden for andre kjelder.

Funna våre kan bidra til å betra utforminga av skriveoppgåver for argumenterande skriving, og er også eit bidrag i den pågåande debatten mellom skriveforskarar verda over om autentiske skrivesituasjonar.

Nøkkelord: skriving, argumentasjon, adressivitet, Toulmin

\section{Introduction}

In Norway, there has been an increasing interest in argumentative writing over the last decade, both in school and in educational research (Solheim \& Matre, 2014). In 2006, the national curriculum was changed to emphasize the fiction and non-fiction genres equally in reading and writing. Within the non-fiction genres, argumentative writing is viewed as especially important, as being able to argue your point of view effectively is a necessary skill for studying in higher education, working in most occupations, and participating in a democracy. This renewed interest is manifested in the national curriculum for both Norwegian language (Utdanningsdirektoratet, 2013a) and Social Science (Utdanningsdirektoratet, 2013b). 
In 2013 the national curriculum was revised and a new competence goal for $12^{\text {th }} / 13^{\text {th }}$ grade was added to the subject of Social Science: "[The students should be able to] debate subjects relevant to social science in digital discussion forums, and consider their own understandings in light of contributions from others" (Utdanningsdirektoratet, 2013b, our translation). This implies a focus not only on the ability to write argumentative texts but also on actually debating in writing with an authentic audience. Still, the role of the audience in students' argumentative writing has received little research attention. In this article, we focus on the connection between student writers of argumentative texts and their audiences. The data for this study were collected in the first year the students were required to discuss topics relevant to social science in online discussion forums due to the new competence goal. We study how students 16 to 17 years of age use arguments in two different communicative situations. The mapping of these practices allows us to discuss how their use of arguments may be influenced by different audiences. Our aim is to discuss the research recommenddations of writing with a purpose and writing for authentic audiences. We regard "writing with a purpose" to refer to the student's purpose for writing, not the teacher's purpose for giving the writing task (Solheim, Larsen, \& Torvatn, 2010). By "authentic audience," we refer to an audience other than the teacher (Otnes, 2013). The term authentic may be understood in different ways, but within writing research there is a long tradition of defining an authentic audience as a real-life audience for which texts are produced and read by someone other than the teacher (Putnam, 2001; Rowan, 2005; Weider, 2012).

In both tasks in our study, the teacher asked the students "to argue." In one task, they wrote for an imaginary audience, and in the other, for an authentic audience. They argued in quite different ways in the two cases. In this article we discuss whether the differences between the argumentation in the different situations can be explained by the audience. The following literature review shows that there is a research gap regarding the influence of the audience on students' texts.

\section{Literature review}

In the first part of this section, we take a look at research on teaching and learning argumentative writing. This helps us identify characteristics in students' argumentative texts. Then, we turn to research on writing with a purpose and writing to an authentic audience in general, to understand how these factors may influence the construction of texts. Finally, we present the theoretic lenses for our analyses of the student texts.

There is considerable research on teaching and/or learning argumentative writing. Teachers often report that they find it difficult to teach students how to write argumentative texts (Andrews, 1995; Berge, 2005; Igland, 2009; Lødding 
\& Aamodt, 2015). Research has also shown that students struggle to master argumentative writing, and when given a choice, they typically prefer assignments other than argumentative writing (Andriessen \& Coirier, 1999; Crowhurst, 1990; Horverak \& Hidle, 2017; Newell et al., 2011). Still, some teaching methods seem to be more effective than others. In a review study of the effects of teaching argumentative writing from 2006 to 2009, Andrews and colleagues sum up what a number of international studies have reported to be the most efficient ways of teaching argumentative writing to 7-14 year-old children:

- A writing process model in which students are encouraged to plan, draft, edit, and revise their writing (De La Paz \& Graham, 2002; Englert et al., 1991; Troia \& Graham, 2002).

- Self-motivation (in the form of personal target-setting-one aspect of self-regulated strategy development) (Graham et al., 2005).

- Some degree of cognitive reasoning training in addition to the natural cognitive development that occurs with maturation (Englert et al., 1991; Ferretti et al., 2000), for example, the self-regulated strategy development suggested by Mason and Shriner (2008).

- Peer collaboration, thus modeling a dialogue that (it is hoped) will become internal and constitute "thought" (Englert et al. 1991).

- Explicit explanations for students of the processes to be learned, although Reznitskaya et al. (2001) suggested that these are less important than peer discussion.

(Andrews, Torgerson, Low, \& McGuinn, 2009, p. 301)

Following this advice, Igland (2009) designed a case study in which students in the $9^{\text {th }}$ grade were taught according to these points, and she studied the texts they were able to produce. Even with exemplary teaching, she found that the students typically expressed strong opinions with poor substantiation. She claimed that what is most difficult - and what is most important in further discussions about written argumentation in school—is teaching the students to be more (self-) critical and exploratory in their approach to debatable questions (Igland, 2009, p. 510). She also discussed the differences and similarities between oral and written argumentation. One difference is that when we write, we need to consider both sides of any case alone, while in oral argumentation we have someone else who delivers the counterarguments: "The implication is that teaching written argumentation necessarily entails the cultivation of strong audience awareness" (Igland, 2009, p. 498). These findings concur with the findings of Øgreid (2017), who claimed that argumentative texts by adolescents often utilize an informal style of writing, with dialogical, appealing, and expressive features. There is a tendency to substantiate claims with personal experiences rather than facts and knowledge, and the texts are often illogically structured (Øgreid, 2017, p. 199).

In our study, we are interested in how different audiences may influence the use of arguments in student texts. We therefore present research on writing with a purpose and writing for different audiences, even if it is not specific to writing 
argumentative texts. Writing in school has often been perceived as a task that serves to satisfy the teacher and has no other purpose. This has been documented in Norwegian writing research, including the SKRIV (WRITE) four-year research project on writing (Smidt, 2010, 2011). Based on their observations, the researchers claimed that giving writing tasks realistic purposes is essential to motivate students, and they argued that writing with a purpose also generates a greater focus on the content and form of the text. In line with this, Norwegian writing researchers developed a theoretical construct, a model of different writing acts and writing purposes, called "The Wheel of Writing" (Berge, Evensen, \& Thygesen, 2016). The distinction they make between writing acts and writing purposes is used in the following. In their article, they present the model and the background for it and list the range of purposes that one may have for writing:

Writing is used in literate cultures for purposes of interaction and information, knowledge storing and structuring, knowledge development, construction of textual worlds and purposes of persuasion. Over cultural-historical time, such purposes have given rise to a wide range of writing practices and genres. (Berge et al., 2016, p. 180)

They combine these writing purposes with different writing acts, presented in a model where each purpose has corresponding writing acts. The different circles of the wheel may be turned separately to illustrate that it is possible to achieve the purpose of persuasion through the writing act of narration (for example):

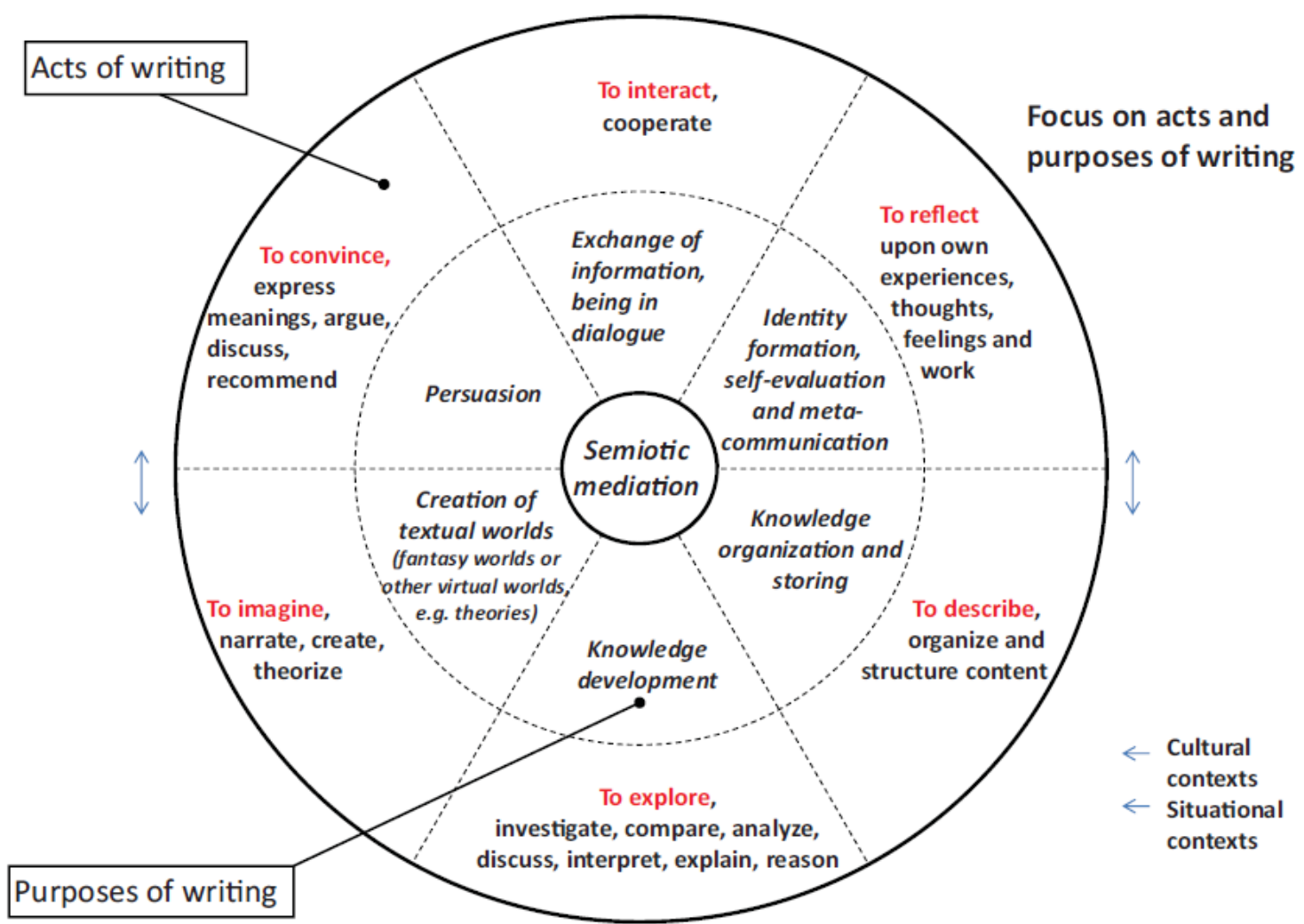

Figure 1. The Wheel of Writing: Focus on intentionalities of writing: Act and purpose (Berge et al., 2016, p. 180). 
Our study focuses on the section of this model which includes the purpose of persuasion and the corresponding writing act to argue. Internationally, schools and teachers have been criticized for putting their students through exercises and activities that serve no other purpose than to practice some specific literacy skill, and the value of such activities has been questioned. The advice, instead, is to make sure writing tasks have a purpose and that literacy activities are authentic (Duke, Purcell-Gates, Hall, \& Tower, 2006; Mills \& Chandra, 2011; Weider, 2012). An authentic communication situation is defined by the audience. The audience should be someone other than the teacher, or, if it is the teacher, it needs to be the teacher as a person, not as an assessor (Iversen \& Otnes, 2016). This topic was also addressed in a large international review of research on teaching and learning argumentative reading and writing from 1985 to 2011.The researchers argued, "With the teacher as the primary audience, students may perceive argumentative writing as simply completing an assignment rather than attempting to change other actual audiences' beliefs or ideas" (Newell et al., 2011, p. 277). In other words, the students often do not know whether their arguments are actually effective because the only feedback comes from their teachers. The homework writing task in our material is a typical example of this situation.

We have not found any research that explicitly studies the use of arguments in student texts in different communication situations. However, Karlsson's (1997) study compares debate letters in a youth magazine, written in answer to a specific post (authentic writing situation), to debate letters answering the same original post, written as a school task (inauthentic writing situation; the letters were not actually sent) (Karlsson, 1997). Karlsson did not study the use of arguments but rather how the students referred to the writing situation (school or magazine) and the kind of background information they gave. She also studied the macro structures of the texts. She found that the simulated letters had references to both situations, lacked background information, and had poorer macro structures than the texts from the authentic situation. She explained these findings based on the double expectations of the students, who were forced to try to communicate in two different communication situations simultaneously.

The PhD thesis by Weider (2012) supports the findings of Newell et al. (2011). Her main research question was "How does the use of technology, online publishing, and authentic audience affect student writing?” (p. 9). In her study of two urban English language arts classes, Weider found that when writing for an authentic audience, the students tended to write better texts than when writing for the teacher alone:

Research data from this study indicated that the use of technology and authentic audience (a purposeful writing environment) do hold the potential to increase student engagement and improve attention to revision by students thereby improving the quality of student writing at school. (Weider, 2012, p. 116) 
The students liked writing for an authentic audience, and they "cared more about their writing because they wanted others to view them as good writers" (Weider, 2012, p. 103). The teacher also reported that the students' writing proficiency had increased. Weider found that other studies supported her findings, and in the conclusion to her literature review she stated, "The preceding literature review indicates that when teachers experimented with social learning pedagogies and provided an authentic audience for their assignments, student writing skills improved" (Weider, 2012, p. 51). Our study examines whether this is also the case when the students are arguing.

The theoretical lenses we apply in this study are grounded in new rhetoric and argumentation theory and can help us understand the writing act of arguing and the role of the audience. In 1929, the Russian literary theoretician Mikhail M. Bakhtin claimed that no utterance is isolated. Every utterance ever madelong or short, written or oral-is always uttered as a response to earlier utterances and with the anticipation of responses to come from whoever reads or hears the utterance. Thus, all utterances are part of an intricate weaving of utterances and must be analyzed as such. Bakhtin (1986) emphasized the role played by the receivers of utterances in communicative settings: "Thus, addressivity, the quality of turning to someone, is a constitutive feature of the utterance; without it the utterance does not and cannot exist" (p. 99). The addressee could be anyone: someone with whom the addresser is engaged in oral conversation, a general audience, or an indefinite someone. In the written genres, the anticipation of the corresponding reaction offers a certain excitement to the utterance and determines the use of stylistic means in the text.

In the 1950s, important contributions were made to the understanding of the role the audience plays in communicative situations. Two books, both published in 1958, have become important references for research on texts in context. The first is The Uses of Argument by Stephen Toulmin, and the second is Le traité de l'argumentation: La nouvelle rhetorique by Chaïm Perelman and Lucie Olbrechts-Tyteca. In 1977, Perelman published a revised version of the book from 1958, stripped down to the essentials, called L'empire rhétorique. Rhétorique et argumentation. Henceforth, we refer to the Danish translation of this book from 2005. Perelman distinguished between the universal audience - a mental image of all rational and competent beings who might receive the argument-and the particular audience-the actual, physical audience that receives the argument in the communicative situation. The speaker or writer must consider both the universal and particular audiences when planning argumentative strategies.

Toulmin (2003) also contributed to the understanding of argumentation by constructing a model of what must be included in an argument. We present Toulmin's model in greater detail in the method section because it is the central tool of analysis of the use of arguments in our study. We used Bakhtin's and Perelman's focus on audience to describe the role of the audience and Toulmin's model to analyze the arguments. 
Turning to the rationale for this study, few of the studies we found examined student texts. Exceptions include the studies by Igland (2009) and Øgreid (2017), but none of these focus on how the audience may influence the use of arguments. We did not find any studies that analyze the arguments in as much detail as we do. Most studies on argumentative writing focus on teaching methods. This leaves a research gap, which our study addresses. Here, we interpret how writers, more or less consciously, analyze their purposes and audiences in two different communicative situations and how they use arguments in the different situations. We analyze the arguments in all the texts in great detail, and to exemplify our findings, we present a close reading of one student's texts from the two different communicative situations. Our research questions are as follows:

What characterizes the use of arguments in the student texts written in two different communicative situations?

How may the different audiences have influenced the argumentation in the different situations?

\section{Methods}

In this section, we present the research design, the data collection process, the analysis tool, and discuss the validity and reliability of our study.

\section{Research design}

The school where the texts were collected is located in a town on the west coast of Norway. It was chosen for practical reasons. It is the only upper secondary school in this town, so a large proportion of the young people who grow up here attend this school. There are four parallel classes at each level, and they are constructed randomly and not, for example, based on level of achievement. Hence, we had reason to believe it would not matter which of the classes we collected our material from. One teacher agreed to let us use his class to collect the data we needed, so we chose that class for study.

The students were studying the subject of crime and punishment with their teacher over a period of three weeks. One of the researchers was present in three of the lessons as a non-participating observer. Afterwards, an entire school day was set aside to work on this subject, and the researcher was present as a participating observer. Her role this day was both to observe and to teach a short session in which Toulmin's (2003) argument model was presented to the students.

The class was required to write two argumentative texts within the same week. The first was a homework assignment on how to prevent crime. The other was an assignment to be completed at school, with the students participating in an online discussion forum on a subject of their choice, relevant to social 
science. Both tasks were formulated and given by the teacher, but he might not have assigned these particular tasks at this time if we had not asked him to give us access to argumentative texts from these two different communicative situations. The students used a day at school to prepare and write their online texts. They studied public debates by reading through comments in online newspapers and on various web sites. The students also learned about Toulmin's argument model. This presentation was meant to remind the students of what an argument is, to show them examples of arguments, and to demonstrate how a claim might have different substantiations. There were 20 students present for the whole day of data collection, and they were asked for written consent to let us use their texts. Seventeen students handed in both texts and agreed to participate. The students have been given pseudonyms in this article to ensure anonymity.

In this study, we analyze the use of arguments in two texts from each of the 17 students who agreed to participate. The conditions under which the two texts were created are quite different, so differences in the texts are to be expected. Next, we describe the conditions in the two communicative situations to increase the transparency of the study.

Both sets of texts were written as school tasks by the same students within the same week. The students had more time to work on their homework text and in theory could have had help in their writing. In contrast, they had to work faster at school and had less opportunity to rewrite their texts.

The wording of the writing tasks also leads to different expectations. The tasks were formulated by the teacher as follows:

a) Write a text of approximately one page in which you argue for how you think we can best prevent crime. (Homework task-must be handed in within a week)

b) Write at least one contribution on a digital discussion forum about a topic relevant to social science. Choose a topic about which you have an opinion and then argue for that opinion. (School task-to be done at school by the end of the day)

In both tasks, the students were asked to argue for a point of view. The communication situation of the homework task is one of assessment. The only reader is the teacher, who is to assess the students' ability to argue in writing about a given theme in the subject of social science. To argue effectively, the students imagine a universal audience that must be convinced of their claims. Consequently, there is no discussion partner in this communication situation (the role of the teacher is only to assess, not discuss), so the student is expected to compose his or her own claims and also to include any opposing arguments in the texts. The implicit text norms include logical claims sustained by reliable arguments and facts. The students should not expect to convince the teacher in the subject matter with their arguments but rather to convince him that they have 
learned something about the topic by their display of knowledge through the arguments to a universal audience.

The communication situation of the online task is different. The texts have an authentic audience because they are published online. The students read other posts before writing, responded to them, and expected answers to their own posts. The texts are therefore a part of an ongoing discussion, and the students can concentrate on their own main claim and arguments, as they can rely on their opponents to present the counterarguments. The implicit text norms include clear opinions, often presented in short texts, and the language is influenced by oral language because of the similarities to an oral conversation. The task of writing these posts was given as a school task, and so one could claim that this too is an inauthentic communication situation. However, they had an audience other than the teacher, and it seems this other particular audience is more important in the situation than the fact that the teacher gave the assignment. Many of the students became so engaged in the discussions that they wrote several posts, even when they were not required to write more than one. They were not asked to turn in the posts to the teacher and were not assessed on their writing accomplishments.

The homework task included a suggested length. It required the students to produce arguments pertaining to a certain topic (regardless of whether they had an opinion) and involved a non-controversial subject on which the students had worked for several weeks and, thus, could be expected to be knowledgeable about. Furthermore, since there are several ways to prevent crime, this task invited multiple claims. The second task was open in length and allowed the students to pick topics they felt strongly about. Since they were likely to have specific opinions on their chosen topics, they were more likely to make a single main claim.

It may seem that there are too many differences between our students' two writing situations to draw any specific conclusions regarding what influenced their writings. We agree, but we still argue for the approach used in this study. We want to examine whether some of the differences can be attributed to the different audiences, and in doing this we are looking for one specific factor that influences the writing. Obviously, comparing texts is a normal activity in all linguistic studies. This is done even though it is never possible to control all of the factors influencing texts written by different persons in different settings. Comparisons may look for similarities or differences between texts. In our case, we are looking for both similarities and differences to find possible influences. First, we look for similarities between texts written in the same writing situations to establish how the argumentation is carried out in each situation. We document these similarities through a close-up analysis of the arguments the students use in each situation. Second, we discuss the differences between the groups of texts from the different situations. Because of the uncertainties mentioned above, it is not possible to definitively conclude that the audience is 
the main influence for the way the students write, but we can point to justifications for that notion.

\section{Data and data collection}

Everyone has a right to attend upper secondary school in Norway, but they can choose between "study specializing" and "vocational" programs. The study specializing program is directed towards students who intend to go on to higher education, while the work-related program allows students to choose between taking a job or further study. We have chosen to collect texts from the study specializing program because argumentative writing can be seen as especially important for higher education.

We have chosen written texts from the subject of social science, even though this is generally regarded as an oral subject in upper secondary school, as the final assessment at the end of the year is an oral exam. Still, the students regularly complete written work such as the homework text in this study. However, the teacher in this case had not been focusing on writing in the subject. The students had been given no special training or education on writing argumentative texts in this subject, but they had received some information about this by their teacher in their Norwegian (L1) studies.

The complete data material for this study consists of 17 texts (posts) retrieved from the online discussion forums and 17 offline texts handed in to the teacher as homework. The online texts consist of the first post each student wrote. Some students wrote several posts during the day, but we chose to use the first text they wrote so that the conditions would be similar for all the students. The term "students' texts" thus covers texts of different lengths, the online discussion posts and the longer homework essays, and these texts are subject to different text norms. The material collection was recommended by the Norwegian Centre for Research Data.

\section{Analytical tool: Toulmin's model}

Our first research question concerns what characterizes the use of arguments in the two texts the students wrote. To answer this question, we needed an analytic tool that could identify and categorize each argument. We used Toulmin's (2003) model to carry out an elaborate in-depth analysis of the students' texts. In this model, each argument is comprised of a claim, a warrant, and data for the claim. The model may also contain backings, qualifiers, and conditions of rebuttal (Toulmin, 2003, p. 37). Toulmin's model was developed further by Brockriede and Ehninger (1960) and adjusted by Jørgensen and Onsberg (2008), suggesting a typology of arguments based on the warrant. We have used the latter typology to categorize the different types of arguments. 


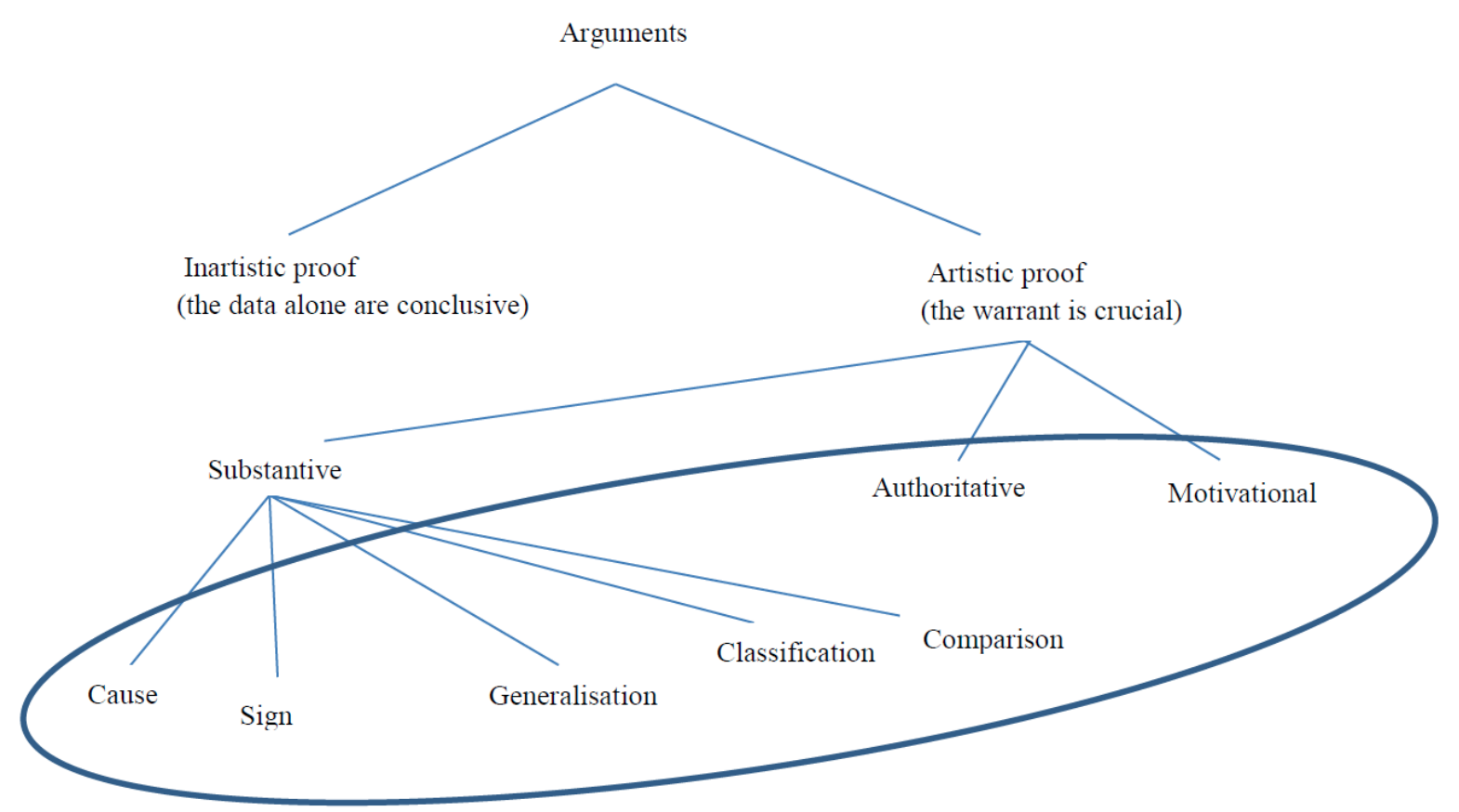

Figure 2. Classification of arguments. Adapted from Brockriede and Ehninger (1960) and Jørgensen and Onsberg (2008).

Authoritative arguments involve "an assumption concerning the quality of the source from which the data are derived," while motivational arguments relate to "an assumption concerning the inner drives, values or aspirations which impel the behavior of those persons to whom the argument is addressed" (Brockriede \& Ehninger, 1960, p. 48). In addition, there are arguments of cause, sign, generalization, classification, and comparison, as shown in Figure 2.

Simply identifying the different elements of each argument would not tell us what we want to know about the students' uses of arguments. It is necessary to combine the analysis of arguments with a typology to get an overview of the argumentative strategies. In our analysis, we identified the main claim(s) in each of the student texts and used Toulmin's model to analyze and describe each argument: What is the claim, what data do the students use to substantiate their claims, and what kind of warrant can be inferred to complete the argument? Then, we used the typology described in Figure 1 to categorize the argument types in each of the student texts. It is impossible to present the complete analysis of all 34 texts here. We have therefore chosen to show our method of analysis by both texts of one student in detail (see the Results section). Based on the overview of arguments used by the group of students (see Table 1), a couple of examples from other texts, and the in-depth analysis of one student's texts, we discuss the question of how the different audiences may have influenced the argumentation in the different situations.

\section{Validity and reliability}

There has been much discussion about how to measure validity and reliability in qualitative research, and different methods have been suggested to ensure and 
measure these criteria. In this study, we sought to ensure the internal reliability by using concepts from established traditions and researchers so that the findings may be compared to those of other studies. To increase the external reliability of the study, both researchers have analyzed all the texts, compared analyses, and resolved disagreements through discussions and refinement of the analyses.

One way to ensure internal validity is to be completely transparent in the analysis, taking the reader through the analysis step by step. There is no room to show the complete analysis of all the texts here, so we have chosen to show the complete analysis of two texts from one student to allow the reader to evaluate whether our analysis is valid in these examples.

External validity refers to how and to what extent the results are valid "beyond the immediate sphere of the study" (Titscher, Meyer, Wodak, \& Vetter, 2000, p. 245). This study is first and foremost a text analysis, and that means what is found in this analysis of these texts cannot automatically be generalized to other texts in other situations. This is a constitutive feature of qualitative research. However, the knowledge acquired may still be interesting or useful for others, through what Postholm (2010, p. 131, our translation) calls naturalistic generalization: "The reader of the text may recognize their own situation in the description, and experiences and findings described in the text may therefore be experienced as useful for their own situation."

\section{Results and analysis}

\section{Different types of argument}

It can sometimes be difficult to establish what counts as a claim in student texts. In our analysis, we tried to identify the main claim in each of the students' texts; however, some of the texts have several claims. Altogether, we analyzed 46 claims in the 17 offline texts and 22 claims in the 17 online texts.

For each claim, there can be one or more pieces of data. A writer will often try to support his or her claim(s) with several pieces of data, and each one requires a warrant (but the warrant may be the same for several pieces of data). For the 46 claims in the homework texts, there were 57 warrants, and for the 22 claims in the online texts, there were 40 warrants.

Table 1. Distribution of different types of warrants online and offline.

\begin{tabular}{lllllc}
\hline & Sign & Cause & Comparison & Authority & Motivation \\
\hline Offline & 1 & 32 & 4 & 11 & 9 \\
\hline Online & 1 & 4 & 3 & 4 & 28 \\
\hline
\end{tabular}

No students made arguments within the classification or generalization categories. We have thus chosen to omit these categories from the table. In the offline 
texts, arguments regarding cause were by far the most common, while motivational arguments prevailed in the online texts.

The most dominant difference between the texts in the two situations was that when writing for the teacher, the students tried to base their claims on facts rather than values. Of the total of 57 warrants, there were 32 warrants from the cause category, 11 from the authority category, 9 from the motivation category, 4 from the comparison category, and 1 from the sign category. This shows that the students strived to base their claims on trustworthy sources or that their claims were drawn as conclusions from cause-and-effect relationships or comparisons. Only 9 of the offline warrants were from the motivational category. When writing to an actual audience, however, the same students tended to use mainly motivational arguments, in which they appealed to the audience's emotions and values. Of the total of 40 online warrants, 28 were from the motivational category. The rest were spread evenly between authority (4), comparison (3), cause (4), and sign (1). To exemplify, we cite an argument from each communicative situation written by one student, Beate:

\footnotetext{
Homework

Claim: The best way to prevent crime is to make sure the prisoners have an opportunity to do okay in society when he or she gets out of jail.

Data: According to an article from the National Statistics Bureau, prisoners who have a job when they are released are much less likely to return to prison than those without a job.

Warrant: Facts documented by the National Statistics Bureau are trustworthy (cause).

\section{Online}

Claim: The death penalty is not a good solution to serious crime.

Data: Everybody should get the chance to change.

Warrant: As long as change is possible, we are (morally) obligated to give everyone the chance to change (motivation).
}

Here we can see that when the student writes with the teacher in mind as the sole audience, she makes sure to substantiate her claim with findings from an article from a source with high credibility in Norway. In doing so, she shows the teacher that she has studied the subject and has knowledge about the subject matter, where to find trustworthy information about it, and how to argue for her claim. In the online text, however, she participates in an ongoing discussion. She has read the posts from others, both her classmates and people from outside the classroom, and is therefore in a more immediate dialogue than when writing to the teacher. The topic is not all that different from the first text, but her argumentative strategies are. Here she states her claim that the death penalty is not a good solution, but her data is that "Everybody should get the chance to change." This is, in fact, simply another claim, and it only functions as data when we apply a warrant from the motivational category, with an appeal to emotions and moral obligations. 
What Table 1 does not show, is that some of the students struggled to keep to the text norms expected in school when asked to write argumentative texts. An example from one student can illustrate this. Nils wrote a homework text with three claims substantiated by cause warrants. Through most of his text, he sticks to this typical method of arguing, and he uses a sober style. However, toward the end of his text, he seems to feel the need to appeal to someone. Instead of only addressing a universal audience, he starts to imagine a particular reader (Perelman, 2005), and turning from his very reasonable arguments, he becomes very expressive and appealing. This may be an example of how the addressivity influences the text:

This might go without saying, but I would like to say it anyway. Don't inject the first syringe, don't steal the first chocolate, don't go through with your first criminal act. Do you really want to see the disappointment in the eyes of your parents when they hear? Was it really worth it? (Nils, final paragraph)

This kind of appeal is much more like the one we find in the online texts, where the arguments that are used are also mainly from the motivational category (see Table 1).

\section{The arguments in more detail}

We have analysed and categorized each argument from all 34 texts. Table 2 shows what types of arguments were used by each of the students in the online text $(\mathrm{O})$ and the homework text $(\mathrm{H})$; each $\mathrm{O}$ or $\mathrm{H}$ symbolizes one warrant.

Table 2. Distribution of the different types of warrants among students $(\mathrm{N}=34)$.

\begin{tabular}{|c|c|c|c|c|c|}
\hline & Sign & Cause & Comparison & Authority & Motivation \\
\hline Anne & & & $\mathrm{OO}$ & & $\mathrm{OOH}$ \\
\hline Beate & & & $\mathrm{OH}$ & OOHHH & $\mathrm{OO}$ \\
\hline Cathrine & & $\mathrm{HHH}$ & $\mathrm{H}$ & $\mathrm{HH}$ & $\mathrm{O}$ \\
\hline Edle & & $\mathrm{HH}$ & & $\mathrm{O}$ & $\mathrm{OOOO}$ \\
\hline Fiona & & HHHH & & & $\mathrm{O}$ \\
\hline Geir & & $\mathrm{H}$ & & & \\
\hline Helge & & $\mathrm{HH}$ & & $\mathrm{H}$ & $\mathrm{OOOH}$ \\
\hline Ingunn & $\mathrm{O}$ & $\mathrm{H}$ & & & $\mathrm{OHH}$ \\
\hline Johan & & $\mathrm{HH}$ & & & $\mathrm{OOOO}$ \\
\hline Kristian & & $\mathrm{H}$ & & $\mathrm{HH}$ & $\mathrm{O}$ \\
\hline Lars & & HHHH & & $\mathrm{H}$ & $\mathrm{OO}$ \\
\hline Marius & & $\mathrm{HH}$ & & & $\mathrm{OOH}$ \\
\hline Nils & & $\mathrm{HHH}$ & & & $\mathrm{O}$ \\
\hline Oda & & $\mathrm{H}$ & & & $\mathrm{OHH}$ \\
\hline Petra & & $\mathrm{HH}$ & $\mathrm{HH}$ & & $\mathrm{OO}$ \\
\hline Rita & $\mathrm{H}$ & OOOOHH & & $\mathrm{HH}$ & \\
\hline Sonja & & $\mathrm{HH}$ & & $\mathrm{O}$ & $\mathrm{OHH}$ \\
\hline
\end{tabular}

Table 2 shows that different students have chosen different strategies in the different writing situations. Some have written elaborate texts with a variety of arguments for their homework assignment, whereas the online posts are short 
and to the point (e.g., Cathrine, Fiona, Kristian, Lars, and Nils). Others have developed their texts and varied their arguments more in the online texts than in their homework (e.g., Anne, Edle, and Johan). Some only provide the bare minimum of one argument in a text-and sometimes not even that. Geir had only one argument in his homework text and no identifiable arguments in his online post, only open questions. However, most students provide more than one piece of data to support their claims.

We have chosen to show the analysis of Cathrine's texts in detail to increase the transparency of the study. As shown in Table 2, Cathrine's home assignment displayed a variety of argument types. Her texts may be said to be among the more successful ones, but they are not unique-two other students also used three different argument types in their homework assignments. Cathrine's text may be said to be typical of the material as a whole, but with above average variety in the use of argument types in her homework text. Cathrine is a typical example in the class when it comes to displaying different rhetorical strategies in the two different situations.

In Cathrine's offline text, we identified as many as six claims supported by data, all of which aim to argue for a view on the question given in the task: How can we best prevent crime? The first claim is an exception because it serves more as a rationale for writing about this topic. An English translation of both texts is included as an appendix. ${ }^{1}$ The following presents the claims from the homework text within the framework of Toulmin's model:

Claim: Crime is a big problem in the welfare state of Norway.

Data: This is supported by statistics from regjeringen.no [government.no].

Warrant: The government website is reliable. We believe in statistics.

Cathrine begins by establishing that the problem she is about to address is worth discussing. Since this statement is supported by statistics from the government, the warrant is from the authority category. She goes on to discuss two distinct kinds of crime: organized and impulsive. Her next claim is that there is something wrong in the Norwegian correctional system. Specifically, if this system worked as intended, there would be no organized crime, and people would not return to prison after their first conviction:

Claim: The fact that crimes like these (organized crimes) are still committed, is a sign that something is wrong with the Norwegian correctional system.

Data: Numbers from the National Bureau of Statistics show that $20 \%$ of inmates return to prison.

Warrant: The National Bureau of Statistics is a reliable source.

\footnotetext{
${ }^{1}$ The language does not always follow correct English grammar or syntax for two reasons: First, to avoid changing the argumentation, we could not stray too far from the original text, and second, the students' language was occasionally not correct in Norwegian. However, we kept all the mistakes from the original texts.
} 
This claim evaluates the Norwegian correctional system. The warrant is from the authoritative category because Cathrine cites the National Bureau of Statistics. Both initial claims show how Cathrine turns to sources outside of herself and her own experience to lend more credibility to her claims. The next claim, however, is of a different kind:

Claim: It is a good idea to go for a big state ${ }^{2}$ in politics.

Data: This has been found to take good care of society, and prevent poverty. (...) To feel socially included in society, and in addition have financial security is, I think, the best prevention we can go for today.

Warrant: A big state will lead to financial security and social inclusion.

The warrant stems from the cause category. Here, Cathrine shows her political viewpoint: in Norway, there is a political divide between the political right, which seeks to limit public "interference" and leave each individual to make his or her own choices, and the political left, which seeks to increase public responsibility for welfare. The next claim is of the same kind:

Claim: All jails should be able to offer education so that the inmates will be able to get on with their lives, psychiatric help to process their problems, and get some life coaching so that they can try to move on with their lives when they get out.

Data: Jail today is supposed to function as a rehabilitation to make criminals ready to at one point return to society as good citizens.

Warrant: Help to education and rehabilitation will lead to fewer recurring convicts.

This is another claim with a warrant from the cause category. Thus, this claim parallels the one above and reveals the same political viewpoint. The next claim, in contrast, is different and was rare in our material:

Claim: More severe convictions will not be effective.

Data: If you look at the USA, they have increased punishment, but this has not led to fewer criminal acts.

Warrant: If it did not work in the USA, it will not work in Norway.

This claim is supported by one of only four warrants from the comparison category. Her final claim is perhaps what she considers to be most important:

Claim: To prevent impulsive crime, it is important to make sure everyone has a healthy childhood and youth.

Data: Childhood and youth are the important times in life, which lay the ground for attitudes and psychological health.

Warrant: Preventive actions during the formative years will prevent crime at a later age.

Here, the warrant belongs to the cause category. In her homework text, Cathrine uses three arguments with warrants from cause, two with warrants from authority, and one with a warrant from the comparison category.

\footnotetext{
${ }^{2}$ By "big state," Cathrine means a large public sector that takes responsibility for its citizens.
} 
Cathrine's text on preventing crime is neatly structured, with an introduction establishing the problem and a main part in which she divides crime into two categories (organized and impulsive). She then discusses one category after the other. She offers different suggestions regarding how crime can be prevented, and her text concludes with a one-sentence summary: "There are many ways to prevent crime in society; we only need to take the time and care to do it.” This is in accordance with the text norms of the school's writing culture-a logical text structure, where claims are substantiated by facts or reliable sources, and the reasoning is logical. In sum, Cathrine exhibits the ability to organize her text based on an acceptable structuring principle, in this case two different kinds of crime. Finding a good structure is one of the problems students have with writing argumentative texts (Andrews et al., 2009; Øgreid, 2017) As mentioned above, Cathrine also uses a variety of argument types (i.e., warrant types) throughout the text, illustrating her understanding that there are different ways to convince the reader (in this case, the teacher). In addition, Cathrine shows that she has a political commitment and that she is up to date on political issues.

Concerning Cathrine's online text, we can see that it is very different from her offline text. The online text has only one main claim. Because Cathrine does not explicitly formulate it, we have to reconstruct it. The text is published in a long thread about same sex marriage from a discussion on Facebook in a group called "political youth":

Claim: We should let people of the same sex marry. (implicit)

Data: Individualism is a fantastic thing, and we cannot brainwash everyone. The only thing we can do is arrange society in the best possible way (...) and let people be who they want to be.

Warrant: We cannot change how people are, so we should accept them as they are.

This warrant comes from the motivation category. Cathrine appeals to the readers' empathy, trying to convince them that it is not up to society to judge other people's choice of spouse. Instead, we should all accept one another as we are and arrange society (including marriage) in a way that allows these differences to be accepted.

The language in this text is much more informal than that in the homework text. It includes slang ("yo"), a meta-comment ("wah, this was messy, but I hope someone gets the point”), and even sarcasm ("peace in the Middle East"). We read this last comment as Cathrine's recognition of the improbability that anyone would change his or her opinion or become more tolerant after reading her message, even if this was the explicit goal of the text. Since the post is a contribution in a discussion thread, there is no need to introduce the topic or otherwise contextualize the content-she can simply express her opinion in response to previous posts. 


\section{Discussion}

As the results section has shown, the types of arguments used in the different communicative situations are quite different. In our first research question, we asked what characterizes the use of arguments in the two different situations. Our findings show that when writing for the teacher, the students mainly use arguments with intellectual appeal. They also use data, such as statistics and facts collected from external sources, more often when writing to the teacher than when they write to the public. When writing to the general public online, students use more motivational arguments with emotional appeal, including appeals to morality and ethics, as shown in Table 1 . This is a more nuanced finding than those found in some of the previous studies of students' argumentative texts. Igland (2009) and Øgreid (2017) both found that the students generally express strong opinions with poor substantiation, often in an informal style of writing, with dialogical, appealing, and expressive features. Their studies concern student texts written as school tasks, with the teacher/principal as the audience. The writing situation is therefore most like our homework task. Their characterization of the texts, however, is more similar to the online texts in our material. Our students are a couple of years older, so perhaps they are more mature and better able to differentiate between different situations and audiences. Igland's and Øgreid's findings show that many students find it hard to write argumentative texts when there is no one to convince. We find examples of this in our material as well, such as the example of Nils, which is presented in the Results section. Øgreid (2017) commented on the dialogical, expressive, and appealing features of students' texts. In Nils's text, we find an example of the need to appeal to someone, even if he is writing in the formal context of school. The task instructs the students to "argue," and it seems that this writing act highlights a need to address a particular audience in addition to the universal audience.

In our second research question, we asked in what way the different audiences may have influenced the argumentation in the different situations. Is it likely that the differences we found in the student texts were caused by the audiences? In our literature review, we presented the Wheel of Writing, a theoretical construct for writing (Berge et al., 2016). The construct presents writing acts and their possible connections to purposes for writing. However, the construct does not explicitly mention the audience. In our study, the predominant writing act is argument, with the purpose of persuasion, but in two different contexts and for different audiences. We find that there are differences in the use of arguments in the students' texts, which can only be accounted for by also considering the audiences.

In the discussion about both purposes and writing acts it may be beneficial to also consider the audience. The writing acts in Weider's (2012) study were mostly intended to inform and reflect, and she found that: 
It was also evident from the observations and interviews with students that writing for an authentic audience of their peers engaged students in their writing at a higher level, they cared more about their work, and were more willing to spend additional time editing and revising to create a quality writing product in order to be viewed as a good writer by their peers. (p. 122)

She also points to the addressees and explains these findings as a result of positive peer pressure. Weider's students were reflecting on a general subject, whereas our students were arguing a point of view. Although Weider's students wrote better texts online than they did for their teacher, the current study shows that the argumentation when written for the teacher was better structured and more varied; when it was carried out in a real-life situation online, it was simplified and more one-dimensional. When writing the online texts, our students relied more on their own moral and ethical judgment as a basis for their claims and appeals (more or less successfully) to the readers' emotions. The difference between reflecting and arguing may thus be crucial. Our findings suggest that the advice of writing for an authentic audience might create problems for the writer when the purpose for writing is persuasion. The positive peer pressure that Weider (2012) found is not present in our study. The different writing acts give the audience different roles. In a reflective (or expressive or creative) text published online, the audience of the online forum functions as supporting peers, helping each other to write better. In an argumentative text on a discussion forum, the audience functions as opponents. We thus find that there are differences in the use of arguments in the students' texts that can only be accounted for by also considering the audience.

One explanation for this might be connected to the differences and similarities between oral and written argumentation (Øgreid, 2017). In writing, we need to pose both sides of the argument, while in oral argumentation, there is an opponent who presents the counterarguments. The same difference applies to our situations: In the homework task, the students must present both sides of the argument, while in the online situation, the opposing arguments are presented by the audience. The online text is therefore (part of) a dialogue with actual attendants, whereas in the homework text, the dialogue is conducted with a universal, fictitious audience (Perelman, 2005). Our findings, then, suggest that it is not differences in purpose, writing situation, or task that generate the differences in the use of arguments, but rather the intended audience.

\section{Conclusion}

We have argued that, in accordance with Bakhtin's (1986) and Perelman's (2005) emphasis on the audience, our findings suggest that the audience is a central feature of the differences between the use of arguments in our two 
studied situations. The small scale of this study can be seen as a limitation to its validity. Other limitations are discussed in the Research Design section: tasks, topics, and communication situations. However, our findings are important because we have investigated something that has not been focused upon in previous writing research. The findings can be used to improve the development of writing tasks and writing practice in school. Since different audiences and writing purposes and different communicative situations lead to such different types of argumentation, it is important that school writing tasks reflect a variety of both communicative situations and audiences and focus on what constitutes a well-functioning argument in different situations. Learning to argue in writing is a very complex process and requires long-term planning and practice through different subjects, situations, and audiences.

Newell et al. (2011, p. 297) called for "studies that occur within the complexities of school and non-school social contexts involving uses of actual, authentic purposes and audiences shaping students' uses of argument.” Our study is a small contribution to the lack of research within this field.

\section{About the authors}

Hege Myklebust is a PhD candidate at Western Norway University of Applied Sciences. Her research interests are writing development, teacher education, and Nynorsk.

Institutional affiliation: Department of Language, Literature, Mathematics and Interpreting, Western Norway University of Applied Sciences, Postbox 7030, 5020 Bergen.

E-mail: hege.myklebust@hvl.no

Sissel Høisæter is associate professor at Western Norway University of Applied Sciences. Her research interests are orality, textbooks, rhetoric, and teacher education.

Institutional affiliation: Department of Language, Literature, Mathematics and Interpreting, Western Norway University of Applied Sciences, Postbox 7030, 5020 Bergen.

E-mail: sissel.hoisaeter@hvl.no

\section{References}

Andrews, R. (1995). Teaching and learning argument. London: Continuum International Publishing Group.

Andrews, R., Torgerson, C., Low, G., \& McGuinn, N. (2009). Teaching argument writing to 7- to 14-year-olds: An international review of the evidence of successful practice.

Cambridge Journal of Education, 39(3), 291-310. 
Andriessen, J., \& Coirier, P. (Eds.). (1999). Foundations of argumentative text processing. Amsterdam: Amsterdam University Press.

Bakhtin, M. M. (1986). The problem of speech genres. In C. Emerson \& M. Holquist (Eds.), Speech genres and other late essays (pp. 60-103). Austin, TX: University of Texas Press.

Berge, K. L. (2005). Skriving som grunnleggende ferdighet og som nasjonal prøve - ideologi og strategier [Writing as basic skill and as national assessment - ideology and strategies]. In A. J. Aasen \& S. Nome (Eds.), Det Nye Norskfaget [The New Norwegian Subject] (pp. 161-188). Bergen Fagbokforlaget.

Berge, K. L., Evensen, L. S., \& Thygesen, R. (2016). The wheel of writing: A model of the writing domain for the teaching and assessing of writing as a key competency. The Curriculum Journal, 27(2), 172-189. doi: https://doi.org/10.1080/09585176.2015.1129980

Brockriede, W., \& Ehninger, D. (1960). Toulmin on argument: An interpretation and application. The Quarterly Journal of Speech, 46(1), 44-53.

Crowhurst, M. (1990). Teaching and learning the writing of persuasive/argumentative discourse. Canadian Journal of Education/Revue Canadienne de l'Éducation, 15(4), 348359.

Duke, N. K., Purcell-Gates, V., Hall, L. A., \& Tower, C. (2006). Authentic literacy activities for developing comprehension and writing. International Reading Association, 60(4), 344-355. doi: https://doi.org/10:1598/RT.60.4.4

Horverak, M. O., \& Hidle, K. W. (2017). Mangelfull opplæring i grunnleggende skriveferdigheter: En studie av barnehagelæreres forkunnskaper for argumenterende skriving i samfunnsfag [Inadequate education in writing as a basic skill: A study of kindergarten teachers' foreknowledge of argumentative writing in social science]. Uniped, 2, 155-169. doi: https://doi.org/10.18261/ISSN.1893-8981-2017-02-05

Igland, M. (2009). Negotiating problems of written argumentation. Argumentation, 23(4), 495-511.

Iversen, H. M., \& Otnes, H. (2016). Å lære å skrive: Tekstkompetanse i norskfagets skriveopplering [Learning to write: Text comptence in writing education in Norwegian]. Oslo: Universitetsforlaget.

Jørgensen, C., \& Onsberg, M. (2008). Praktisk argumentation [Practical argumentation] (3. ed.). København: Nyt Teknisk Forlag.

Karlsson, A. (1997). Textnormer i och utanför skolan - att skriva insändare på riktigt och på låtsas [Text norms in and outside of school - writing letters to the editor for real and pretend]. In G. Håkansson (Ed.), Svenskans Beskrivning [Describing Swedish] (pp. 172186), Lund: Lund University Press (Volume 22).

Lødding, B., \& Aamodt, P. O. (2015). Studieforberedt etter studieforberedende? Overgangen mellom studieforberedende utdanningsprogram og høyere utdanning belyst gjennom gruppesamtaler med lerere, studenter og elever [Prepared for studies in higher education after study specializing program? The transition beteween study specializing program and higher education enlightened by group conversations with teachers, pupils and students] (Report no. 28). Oslo: NIFU. Retrieved from https://www.udir.no/globalassets/filer/tallog-forskning/forskningsrapporter/nifurapport2015-28.pdf

Mills, K. A., \& Chandra, V. (2011). Microblogging as a literacy practice for educational communities Journal of Adolescent \& Adult Literacy, 55, 35-45. doi: https://doi.org/10.1598/JAAL.55.1.4

Newell, G. E., Beach, R., Smith, J., VanDerHeide, J., Kuhn, D., \& Andriessen, J. (2011). Teaching and learning argumentative reading and writing: A review of research. Reading Research Quarterly, 46(3), 273-304. 
Otnes, H. (2013). Fiktive skriveroller og ukjente mottakere: Kontekstualisering i skriveoppgaver [Fictitious writing roles and unknown audiences: Contextualizing in writing tasks]. In E. Maagerø, B. Aamotsbakken \& N. Askeland (Eds.), Lcreboka: Studier av ulike lereboktekster [The textbook: Studies of different textbook texts] (pp. 201-214). Oslo: Akademika Forlag.

Perelman, C. (2005). Retorikkens rige [The kingdom of Rhetoric]. København: Hans Reitzlers forlag.

Postholm, M. B. (2010). Kvalitativ metode. En innføring med fokus på fenomenologi, etnografi og kasusstudier (2. utg.) [Qualitative method. An introduction focusing on phenomenology, ethnography, and case studies (2nd ed.)]. Oslo: Universitetsforlaget.

Putnam, D. (2001). Authentic writing using online resources: Selling our words in the community. The English Journal, 90(5), 102-106.

Rowan, D. (2005). The write motivation: Using the internet to engage students in writing across the curriculum. Learning \& Leading with Technology, 32(5), 22-23.

Smidt, J. (2010). Skriving i alle fag: Innsyn og utspill [Writing in the content areas: Insights and initiatives]. Trondheim: Tapir Akademisk Forlag.

Smidt, J. (2011). Ti teser om skriving i alle fag [Ten theses on writing in the content areas]. In J. Smidt, R. Solheim, \& A. J. Aasen (Eds.), På sporet av god skriveopplering - ei bok for lerere $i$ alle fag [On the track of good writing instruction - a book for teachers of all subjects] (pp. 9-42). Trondheim: Tapir akademisk forlag.

Solheim, R., Larsen, S. A., \& Torvatn, A. C. (2010). Skrivekulturar på mellomtrinnet - tre døme [Writing cultures in the upper primary level - three examples]. In J. Smidt (Ed.), Skriving i alle fag - innsyn og utspill [Writing in all subjects: Insights and initiatives] (pp. 39-65). Tapir akademisk forlag.

Solheim, R., \& Matre, S. (2014). Forventninger om skrivekompetanse: Perspektiver på skriving, skriveopplæring og vurdering i "normprosjektet" [Expectations of writing compence: Perspectives on writing, writing education and assessment in the «norm project»]. Viden Om Lesning, 15, 76-89.

Titscher, S., Meyer, M., Wodak, R., \& Vetter, E. (2000). Methods of text and discourse analysis. London: Sage Publications Limited.

Toulmin, S. (2003). The uses of argument (Updated ed.). Cambridge: Cambridge University Press.

Utdanningsdirektoratet (2013a). Læreplan i norsk [National curriculum in Norwegian] (NOR1-05). Retrieved from https://www.udir.no/kl06/NOR1-05

Utdanningsdirektoratet (2013b). Lcereplan i samfunnsfag [National curriculum in Social science] (saf 1-03). Retrieved from https://www.udir.no/kl06/SAF1-03

Weider, L. M. (2012). Online publishing and authentic audience to improve student writing $\mathrm{PhD}$ thesis, College of Professional Studies, Northeastern University, Boston, MA. Retrieved from http://hdl.handle.net/2047/d20002945

Øgreid, A. K. (2017). Bruk av modelltekster i arbeidet med skriftlig argumentasjon: En studie av åttendeklasseelevers skriving i RLE-faget [Using model texts in the education of written argumentation: A study of eigth graders' writing in the subject Religion, Beliefs and Ethics]. In N. G. Garmann \& Å. M. Ommundsen (Eds.), Danne og utdanne: Litteratur, språk og samtale [Education: Literature, language and conversation] (pp. 199226). Oslo: Novus Forlag. 


\section{Appendix}

The following are the complete texts written by one student, translated by the authors of the article. The language does not always follow correct English grammar or syntax for two reasons: First, to avoid changing the argumentation, we could not stray too far from the original text, and second, the student's language was occasionally not correct in Norwegian.

\section{Cathrine's text to the teacher:}

Crime is a big problem in the welfare state of Norway. According to statistics from regjeringen.no [government web site], the crime rate went up from 1993 to 2009 by approximately $15 \%$, and reached its peak in 2003. But we can see that the crime rate is on its way down. What can we do to prevent crime? The society we meet today is well-equipped with different support systems, but they don't seem to work. Why not?

First, I would like to address organized crime. Organized crime is planned by persons or groups before they happen, before the crime is committed. The most common kind of organized crime is crime for profit - where there is a personal profit in it for the criminal. The causes can be found in the environment, either economic or social causes, but this does not mean we should take the blame from the criminal. The fact that crimes like these are still committed, is a sign that something is wrong with the Norwegian correctional system. Numbers from the national bureau of statistics show that app. $20 \%$ of all inmates in Norwegian prisons return to crime within 2 years of their release.

To prevent this kind of crime, I think that it is a good idea to go for a big state in politics, since this has been found to take good care of society, and prevent poverty, as opposed to the liberal side which is mostly every man for himself. To feel socially included in society, and in addition to have financial security is, I think, the best prevention we can go for today.

This can also be a result of bad attitudes and values, which lead to that the person in question is not able to understand the difference between right and wrong. Then it is important to create a stable and good childhood environment. I will elaborate on this when it comes to impulsive crime.

What can we do for those who are already in jail, to prevent a relapse? Jail today is supposed to function as a rehabilitation to make the criminals ready to at one point return to society as good citizens, but they shall also understand that what they have done is wrong, so they shouldn't be treated with kid gloves.

All jails should be able to offer education, so that the inmates will be able to get on with their lives, psychiatric help to process their problems, and get some life coaching, so that they can try to move on with their lives when they get out. After the ex. convict gets out, there should also be a care and support system to follow up and be available for the coming ups and downs. But I don't think harder convictions will have any good effect. If you look at the USA, which is at 
the top of crime rates in the world, they have tried to increase the punishment without this leading to fewer criminal actions.

Then there is the so-called impulsive crime, which often are crimes of violence and assault. These are crimes that are performed without premeditation, i.e., impulsively. These are often caused by psychiatric illness and/or use of different intoxicating substances, like alcohol or narcotic drugs.

This kind of crime can to a high degree be controlled by environment and society, where the basis for psychological health and attitudes is formed at an early age. A closer follow-up of parents to be, where their ability to function as parents is evaluated, the same way it is in adoption cases, would be ideal. A larger child services department, with more resources, I would think could help a lot. Values and attitudes are formed when the child is between five and twelve. This is when it learns how the world works, through role models who should be able to offer a solid basis of good attitudes.

The adolescence is the time when most criminals start their acting out. During this time, it is important to have preventive measures like youth clubs, 'utekontakt' [a public service found in most Norwegian municipalities, designed to prevent intoxication and crime among young people], and visible health care within the school system. Anonymous resources online, and telephone lines are also good support systems for adolescents today, when many might need help to deal with this time of their lives. If you can deal with this period, the odds are better for the rest of your life.

There are many ways to prevent crime in society, we only need to take the time and care to do it.

\section{Cathrine's text online:}

If we could only accept people like they are. Forget what sex they belong to, what denomination they belong to, and what sex they are attracted to. This is not the point in politics. Politics is about making the best choices for the society as a whole, and we should soon realise that individualism is a fantastic thing, and we cannot brainwash everyone. The only thing we can do is arrange the society in the best possible way, independent of small details. Try to look at the bigger picture instead, and let people be who they want to be. A realistic view of the world is important. Wah, this was messy, but I hope someone gets the point and become more tolerant. Both religious and atheists. Peace in the Middle East, yo. No... 